\title{
The effect of supply chain linkages on the business performance: Evidence from Vietnam
}

\author{
Thi Thu Cuc Nguyen ${ }^{a}$, Quang Bach Tran ${ }^{a}$, Dieu Anh Ho ${ }^{a}$, Duc Anh Duong ${ }^{b}$ and Thi Bich Thuy Nguyen ${ }^{a}$
}

${ }^{a}$ Lecturer, Faculty of Economics, Vinh University, Vietnam

${ }^{b}$ Lecturer, Faculty of Foreign Languages, Vinh University, Vietnam

\section{H R O N I C L E}

\section{Article history:}

Received April 2, 2021

Received in revised format May

15,2021

Accepted June 102021

Available online

June 142021

Keywords:

Supply chain linkages

Trust

Business strategy orientation

Opportunistic behaviors

Business performance efficiency

\section{A B S T R A C T}

The study aims to examine the impact of supply chain linkages on the performance of businesses. Quantitative research is used by implementing the analysis of the SEM linear structure model. A survey is conducted consisting of 598 samples - experienced managers who had the knowledge of the management of supply chain activities in enterprises in Vietnam. Research results show that supply chain linkages, although not having a direct impact, has an indirect impact on the business performance of enterprises through the intermediary factors of trust and business strategy and the opportunistic behaviors of the participating members. Also, research has demonstrated that opportunistic behaviors have negative effects on trust among members of the supply chain.

\section{Introduction}

As the economy grows and becomes more specialized (Lummus \& Vokurka, 1999), organizations will tend to increase cooperation with other members of the supply chain to mobilize quality resources of the partner at a lower cost than to selfproduce ineffectively. Therefore, organizations increasingly want to come together to effectively manage supply sources as well as distribution channels to both optimize costs and increase customer satisfaction, contributing to improving the competitiveness and profitability of participating organizations (Lee \& Whang, 2000; Anderson \& Narus, 1990). Therefore, many researchers agree that: competition is taking place between supply chains, not between businesses and firms (Christopher, 1998). Supply chain management practices have become strategic resources and capabilities for enhancing both competitive advantage logistic performance (Kankaew et al., 2021). Many scholars argue that supply chain linkages are caused by global competition pressures (Handfield and Nichols, 1999), or risks from environmental volatility including changes in supply, demand, and technology (Chen \& Paulraj, 2004; Mentzer et al., 2001), new market opportunities (Frohlich \& Westbrook, 2001). Venkatraman and Ramanujam (1986) contend that business performance is a factor that is of interest not only in managers, leaders in organizations and enterprises but also receives a lot of attention from researchers with different aspects such as terminology, level of analysis (individual, group, the department, etc.). Business performance of an enterprise can be viewed in terms of financial results, non-financial results, or a combination of these indicators. There are many ways and criteria to measure the business performance of an enterprise in the supply chain management context. Business performance can be measured from three perspectives: resource use, outcomes, and flexibility (Beamon, 1999). So far, in their studies, many authors have mentioned the relationship between supply chain linkages and the business performance of the business. Linkages in the supply chain can also be seen as an important resource to build up advantages over competitors and improve the business efficiency of enterprises (Harrigan, 1984). Efficient supply chain linkages will improve customer satisfaction, decrease costs, and increase profit (David, 1993). Besides, the association and cooperation between members in

* Corresponding author

E-mail address: tbach152008@gmail.com (Q.B. Tran)

C 2021 Growing Science Ltd. All rights reserved.

doi: $10.5267 /$ j.uscm.2021.6.009 
the supply chain will help enterprises expand their market share, reduce costs and ensure sustainable development (Lee \& Whang, 2000). Participating in the supply chain helps to improve the profits, competitive advantages, and customer satisfaction of enterprises (Jones \& Riley, 1985; Stevens, 1989). Low costs and differentiation in customer service increase the competitive edge of the entire supply chain (Cooper et al., 1997; Tyndall et al., 1998). Linking in the supply chain effectively will increase the operational results and business efficiency, at the same time increase customer satisfaction and competitive advantage, ultimately increasing the profitability of enterprises (Giunipero \& Brand, 1996; La Londe, 1998). Thus, there have been many studies on the relationship between supply chain linkages and the business performance of enterprises (Droge et al., 2004; Flynn et al., 2010 ...). However, studies do not show mixed results. Therefore, it is necessary to have a clear definition, scale standardization, and further testing in other contexts (Fabbe-Costes \& Jahre, 2008). Most Vietnamese enterprises are small and medium-sized, although they are considered to have significant progress in many fields, many enterprises are limited, fragmented, small, and lack clear business strategies, which leads to unsatisfactory business performance. In the market economy, the risk is always an important issue when participating in production and business activities. Up to now, many businesses in Vietnam are still confused in defining strategies and how to coordinate them to reduce risks as well as promote supply chain linkages. Enterprises that want to limit risks, create a position in the market, besides solutions to promote their competitiveness, the linkage is an effective way, thereby helping businesses increase ownership and improve productivity and operational efficiency of the organization. Research bases on theoretical overview and related works have built models and tested the impact of supply chain linkages on the business performance of the enterprises. With the context of enterprises in Vietnam, besides showing the importance of the relationship with customers and suppliers, the study also demonstrates the mediating role of the factors of trust, business strategy direction, and opportunistic behaviors of participants in the relationship between supply chain linkages and business performance. These are meaningful contributions in both theory and practice, which helps businesses get more insight about supply chain linkages as well as their impact on the business performance of the enterprises, thereby offering more effective solutions and policies in the future.

\section{Literature Review and Hypotheses}

\subsection{Supply Chain Linkages and Business Performance of the Enterprises}

According to Zelbst et al. (2009), while organizational managers are ultimately held accountable for the performance of their organizations, the success of their organizations depends heavily upon the success of the supply chain in which the organization participates as a partner. Based on the development of the supply chain linkages concept in both practice and theory, Bechtel and Jayaram (1997) divided four different schools of concept about supply chain linkages: (1) the "linkage/logistics school", which assumes that supply chain linkages are the links of logistics activities; (2) the "information school" which implies linking information lines both inside and outside enterprises; (3) the "integration/process school" which is the concept of linking business processes between enterprises in the supply chain; (4) the "functional chain awareness school" which separates supply chain linkages into external links (linking between enterprises) and internal links. Meanwhile, many other studies on supply chain linkages focus on studying the links between organizations, individuals, and businesses. Specifically, the link between enterprises and customers, links with suppliers, or links from suppliers, manufacturers, and through intermediaries to end consumers (Swink et al., 2007). Linking with customers to determine the right needs of customers and thereby mobilize the necessary resources to create products and services that customers want. Working closely with the customer reduces the risk from market volatility, at the same time improving the efficiency of production and ultimately increasing company profits (Enkel et al., 2005). Besides linking with customers, linking with suppliers is also focused. Linking closely with suppliers to always be guaranteed to provide inputs such as raw materials, machinery, equipment, experts, and even valuable information ... to ensure smooth and timely delivery in the process of manufacturing and distributing products and services to customers (Klein \& Rai, 2009). According to Nielsen (2019), the fields of business and innovation are both concerned with the broader notion of future value creation. Neely et al. (1995) claim that business performance is a set of criteria to quantify the efficiency of all aspects of enterprises. It is verified by 03 levels: individuals, enterprises' goals, and the relationship between such evaluation criteria with the operating environment (culture, customer satisfaction, development strategy...). Maisel (2001) evaluates the business performance of enterprises as a system that helps enterprises to plan, measure and control the results of sales, marketing, information technology activities, and business decision-making... and other activities aim for enterprises to set goals and create value for people with related interests. According to Kaplan and Norton (1993), the business performance of enterprises is determined from 04 basic groups of components, including finance, customers, internal processes, and developmental learning. It builds the basis for converting the content of the business strategy into execution terms. The research of Delaney and Huselid (1996) which measures the business performance of enterprises does not based on financial ratios but employees' perception of the organization's performance, and base on criteria such as production quality, product development, ability to attract employees, customer satisfaction and the relationship between managers and employees as indicators of the performance of management at enterprises. The measurement based on perceptions has a positive impact on the business performance of enterprises (Dollinger \& Golden, 1992). In addition to the two directly impacting factors mentioned in the research content, the supply chain linkages, and the business performance of the enterprises. The study also mentioned mediating factors including trust, business strategy direction, and opportunistic behaviors of members participating in the supply chain. Trust is one of the factors that make the relationship effective. Maryer et al. (1995) argue 
that trust is the belief of one object with another and point out the need to clarify the concept of trust in the relationship between the one who harbors the belief and the subject of this affection, trust begets trustworthiness and trust in others (Cohen \& Isaac, 2021). In the supply chain partnerships, building trust among the participants is considered an urgent requirement, affecting knowledge sharing, work productivity, thereby promoting the efficiency of enterprises' business performance. The strategy is the plan to achieve the long-term goals of the organization (Higgins \& Vincze, 1989). In other words, strategy influences the performance of an organization's activities (Porter, 1985). Strategic orientation is the specific approach that an organization chooses to implement strategies to create competitive advantages and improve business performance (Gatignon \& Xuereb, 1997). The strategic direction defines the strategic goals and directs all activities of the organization, including supply chain linkages. In the field of supply chain management, there are two basic strategic directions related to supply chain linkages: low-cost strategy and customer-oriented strategy (Porter, 1985). The client's strategic orientation can also mean enterprises' long-term development plans which are based on the needs of customers, not the needs of other entities such as owners, managers, or employees (Deshpande et al., 1993). enterprises deeply understand their target customers and create continuous added value for them (Narver \& Slater, 1990). Thus, it can be understood that a customer-oriented strategy is a long-term plan aiming to deeply understand customer needs and always create added value for customers. A low-cost strategy is aimed at finding and efficiently exploiting resources that offer a lower cost advantage over competitors (Porter, 1985). Enterprises oriented towards this strategy often focus on tightly controlling costs related to business processes such as control of inventory, raw materials, and production, or low-cost, but effective investment activities such as R\&D, services, and marketing (Martin \& Grbac, 2003). However, the pursuit of low cost can affect the quality of customer service. In partnership, the members' behaviors include both positive and negative behaviors. Opportunistic behaviors are acts of seeking personal interests through fraud (Williamson, 1975), the nature of which is a breach of commitments, violation of obligations, or liability required to be performed (Morgan \& Hunt, 1994). According to Nguyen et al. (2020), opportunistic behaviors are considered as negative behaviors, dominated and determined by perceptions, attitudes, and capacities of individuals and organizations.

\subsection{Research Hypotheses}

\subsubsection{Supply Chain Linkages and Business Performance}

The relationship between linkage in the supply chain and the business performance of enterprises are studied under different angles. From a supply chain perspective in general, linkage implies links with suppliers and with customers (Li et al., 2006). This view can also imply the relationship between the buyer and the seller from a logistics perspective (Paulraj, 2007). In general, most researchers think that external links have an impact on the business performance of enterprises. Li et al. (2006) claim that supply chain linkages and management have a direct and long-term impact on a firm's marketing and financial performance. Linking logistics operations with suppliers and customers improves the efficiency of both sellers and buyers (Paulraj, 2007). From a supply chain perspective in general, Li et al. (2006) demonstrated the impact of supply chain linkages on long-term marketing and financial performance. In the scope of logistics, Paulraj (2007) also discovered a relationship between the linkage of logistics activities between enterprises and the business performance of each enterprise participating in the association. Although many studies confirm the impact of supply chain linkages on the business performance of enterprises. However, this relationship is only partially confirmed in several other studies. Specifically, while the degree of association affects the sales-to-asset ratio, it does not affect the increase in customer satisfaction and sales (Rosenzweig et al., 2003). Similarly, Vickery et al. (2003) confirm a failure to find evidence of the effect of supply chain linkages on the ratio of revenue before tax to total assets (ROA). Collaboration with key suppliers and key customers will reduce costs, improve product design and quality and service quality. And finally, the above improvements will help improve productivity, while also improving business results. With the context of enterprises in Vietnam, to test more clearly the relationship between supply chain linkages and the business performance of the enterprises, the hypothesis is set out:

\section{H1: Supply chain linkages positively affect the business performance of enterprises in Vietnam (see Fig. 1).}

\subsubsection{Linkages and Trust among Members of the Supply Chain}

George and Jones (1996) said that satisfaction is a set of feelings and beliefs of members with the job. Creating sustainable linkages in the responsive chain improves the satisfaction of the participants, creates proactivity in operations, reduces costs, and increases profits (David, 1993). Also, the association and cooperation between members in the supply chain will help enterprises expand their market share, reduce costs and ensure sustainable development (Lee \& Whang, 2000). To examine and clarify the direction of the impact of the association on trust among members in the supply chain in the context of enterprises in Vietnam, the hypothesis is proposed:

\section{$\mathbf{H}_{2}$ : Linkages positively affect trust among members in the supply chain in Vietnam (see Fig. 1).}

\subsubsection{Trust among Members in the Supply Chain and Business Performance}

Bakiev (2013) argues that the mediated high-performance system is the relationship between trust, organizational cohesion, and organizational performance perceptions that have a positive effect on the business performance of enterprises. Guinot et 
al. (2014) argued that trust among participants is a factor that positively affects the business performance of organizations. With most research results, the same point of view is that trust among members in the supply chain has a positive impact on the performance of enterprises such as the research of Klein and Rai (2009). However not all studies have found a positive relationship between trust and business performance. In partnership, building trust among members is one of the necessary solutions, having an impact on the effectiveness of management decisions, and at the same time affecting the productivity of enterprises. So, in the context of enterprises in Vietnam, trust among members in the supply chain will affect the business performance of enterprises. The hypothesis built:

$\mathbf{H}_{3}$ : Trust among members in the supply chain positively affects the business performance of enterprises in Vietnam (see Fig. $1)$.

\subsubsection{Supply Chain Linkages and Business Strategy Direction}

Grant (1991) argues that low-cost strategic-oriented firms tend to promote supply chain linkages. Through association, enterprises will increase the chance of exploiting resources from their partners more effectively. Customer strategic orientation often places the highest priority on providing the best value to customers. To do that, enterprises need a high consensus in changing their organizational structure, shifting from focusing only on efficient exploitation of internal resources, to strengthening cooperation to achieve the above goal (Han et al., 1998). Creating sustainable links in the supply chain helps participating members feel secure and proactive in all activities. The association goals will be the core directions from which to outline the plans and directions for enterprises in certain periods. To examine more clearly the relationship between supply chain linkages and the direction of business strategy, with the context in Vietnam, the authors propose:

\section{H4: Supply chain linkages positively affect the business strategy direction of businesses in Vietnam (see Fig. 1).}

\subsubsection{Strategic Orientation and Business Performance}

The appropriateness between the strategy and the structure of enterprises will positively affect the business performance because the organizational structure creates the systems and process of implementation or implementing successful business strategies. public (Habib \& Victor, 1991). Strengthening links with suppliers can also help enterprises enjoy preferential regimes, including preferential treatment on commodity prices, thereby reducing input costs, improving the efficiency of enterprises' business activities. In the case of enterprises in Vietnam, to test the relationship between strategic direction and business performance, the following hypothesis is proposed:

\section{H5: Strategic orientation has positive impacts on the business performance of enterprises in Vietnam (see Fig. 1).}

\subsubsection{Linkages and Opportunistic Behaviors of Supply Chain Members}

The opportunistic behaviors in relationships often exist and have a significant influence on the working performance of organizations. opportunistic behaviors are often negatively associated with supply chain linkages risks such as not satisfying the needs of partners or compromising the safety of the business (Zsidisin, 2003). High-risk markets are characterized by the constantly changing and unpredictable needs of customers and organizations in their commitments. Enterprises often have difficulty in doing business when operating in such an environment (Trkman \& McCormack, 2009). With the context of enterprises in Vietnam, to clarify the relationship between the linkage and the opportunistic behaviors of members in the supply chain, the authors hypothesize:

H6: Links have a negative impact on the opportunistic behaviors of supply chain members in Vietnam (see Fig. 1).

\subsubsection{The Opportunistic Behaviors of Supply Chain Members and Business Performance}

According to Katsikeas et al. (2009), there is a link between opportunity behaviors and trust, which affects the business performance of enterprises. If there are more negative opportunistic behaviors, they will affect the productivity of both individuals and organizations, leading to reduction in business performance (Nguyen et al., 2020). Opportunity behavior often stems from the individual needs and interests of each organization. In this relationship, needs determine interests. Performance depends on the relationships among the participants, tolerance, adaptability, and teamwork, which are also important behaviors of each member. Business performance, if dominated by personal interests, will have a negative impact. Most research has shown the impact of the opportunistic behavior of members in the supply chain on the business performance of enterprises. Thus, with the context of Vietnamese enterprises, whether there is a direct relationship between the opportunity behavior of the members in the supply chain on the business performance of enterprises or not. The hypothesis is set forth:

$\mathbf{H}_{7}$ : The opportunity behavior of members in the supply chain has a negative impact on the business performance of enterprises in Vietnam (see Fig. 1). 
Morgan and Hunt (1994) in their research have shown that there is an adverse effect of opportunistic behaviors on trust in relationship marketing activities. Trust has a negative impact on the opportunistic behavior (Tran et al., 2021). To maintain their activities and towards more success, many organizations and individuals do not exclude opportunistic behaviors to create their interests, which have a significant impact on the trust of members participating in the supply chain and the overall performance of organizations. To establish the impact relations between the opportunistic behaviors and beliefs among members in the supply chain. The authors hypothesize:

H8: The opportunistic behaviors have a negative impact on trust among members in the supply chain in Vietnam (see Fig. 1).

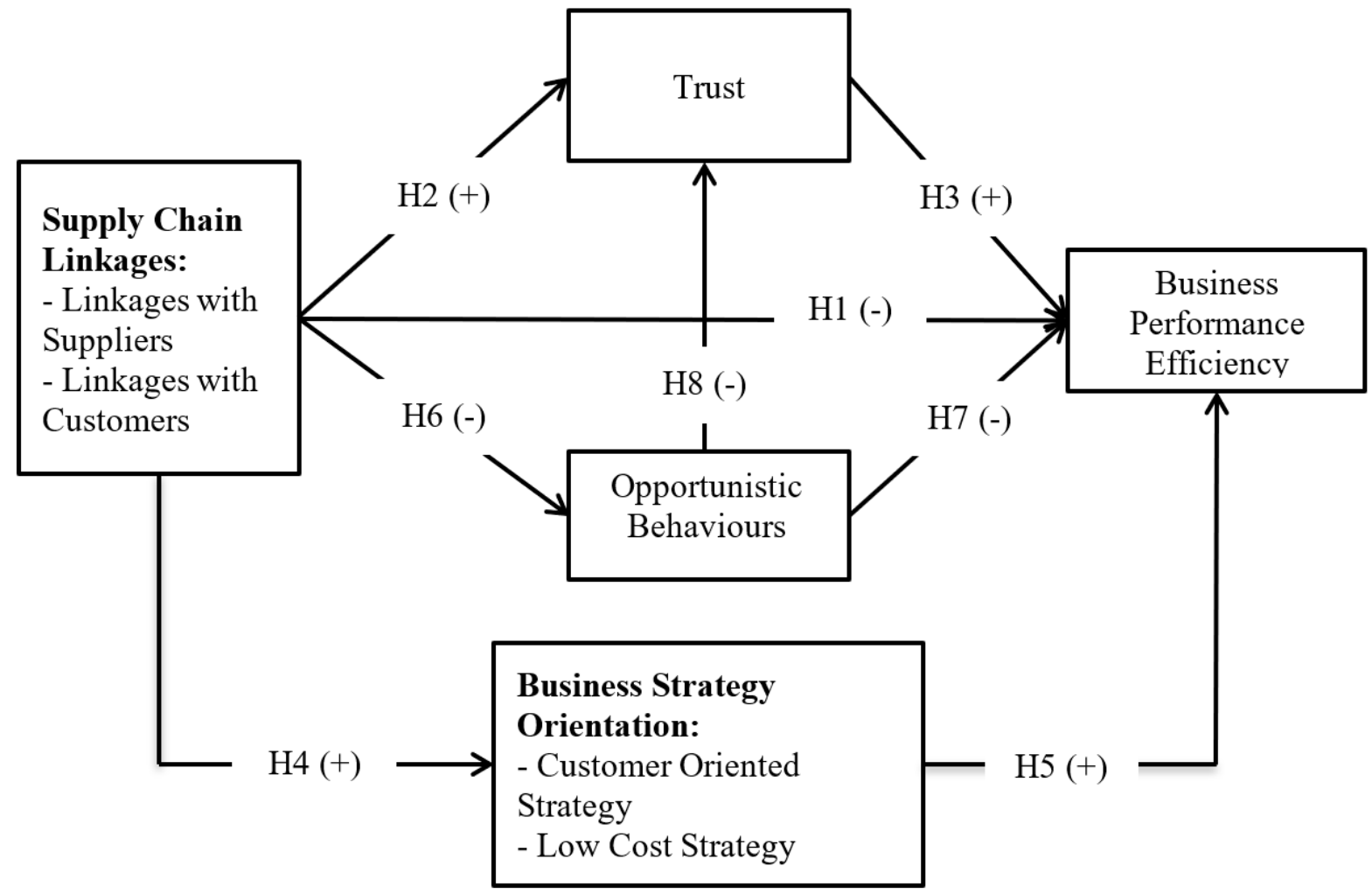

Fig. 1. Proposed Research Model

\section{Research Method}

\subsection{Research Scale}

Based on theoretical overview and related research works, the article proposes a research model with independent variables as supply chain linkages including Supplier Link and Customer Link; The intermediary variable selected is Trust, Opportunistic Behavior, and Business Strategy Direction including Customer-oriented, Low-cost strategy; The target variable is Business performance. The scale used in the study is a Likert scale with 5 levels (Strongly agree; Agree; Normal; Disagree; Strongly disagree). Variable measurement indicators are applied with adjustments to the characteristics of the research sample from previous studies. The supply chain linkages variable (SCL) uses the research scale of Zhao et al. (2013) includes 13 observations with 2 groups of factors: Linkages with the suppliers (LS) with 7 observations; Linkages with customers (LC) has 6 observations; Trust (TR) uses the scale of Morgan and Hunt (1994) with 5 observations; Opportunistic behaviors (OPB) using the scale of Katsikeas et al. (2009) includes 5 observations; Business Strategy Orientation (BSO) using the scale of Deshpande and Farley (1998) includes 10 observations with 2 groups of factors: Customer-oriented strategy (COS) has 5 observations and Low-cost strategy (LCS) has 5 observations; Business performance (BP) using the scale of Huselid (1995) includes 6 observations.

\subsection{Research Sample}

The research sample was selected by the non-probability sampling method which is convenient sampling, relatively stratified according to the provinces and localities in Vietnam. The subjects of research in the study are those who are identified as 
managers with experience and knowledge of the management of supply chain operations in enterprises in Vietnam. The sample size for data analysis was 598 samples. The data collection process is conducted in two ways: direct ticket distribution and online. The number of online votes collected is 357 , the number of available votes is 324 . In direct terms, the number of votes given out was 400, the number of votes received was 296, the number of available votes was 274 . The total number of valid votes used for analysis is 598. According to Hair et al. (1998) for reference on expected sample size, the minimum sample size is 5 times the total number of observed variables. With the number of observations in the article is 39 , the research scale includes 598 samples to ensure analysis requirements. The time to complete data collection is October 2020 to December 2020 .

\subsection{Data Processing}

Research using quantitative methods. Data collected and cleaned are processed through SPSS and AMOS programs. First, assess the reliability of the scale with the requirement that Cronbach's Alpha value $>0.7$. Next, research factor analysis to discover EFA to determine "convergence value" and "differential value of the scale" and with required factor load factor (Factor loading) $>0.5$, KMO coefficient $>=0.5$ and $<=1$, Sig value. $<0.05$, and the percentage of variance extracted $>50 \%$. Then, AMOS software is used to evaluate the suitability of the research model through the CFA test and finally test research hypotheses by analyzing the SEM linear structure model with the requirements of chi-square/df index $<5$ in case of sample size $\geq 200$ (Kettinger et al., 1995); GFI, TLI, CFI > 0.8, RMSEA <0.08 (Taylor et al., 1993).

\section{Results and Discussion}

\subsection{Testing the Reliability of the Scale}

Cronbach's Alpha test analysis results show that the reliability of the scale used in the analysis when Cronbach's Alpha coefficients of all variables are $>0.7$ (see Table 1 ).

Table 1

Evaluation of the reliability of the scale through Cronbach's Alpha coefficient

\begin{tabular}{llcc}
\hline No. & Variables & Ref. code & Cronbach's Alpha \\
\hline $\mathbf{1}$ & Linkages with the Suppliers & LS & 0.891 \\
$\mathbf{2}$ & Linkages with Customers & LC & 0.735 \\
$\mathbf{3}$ & Trust & TR & 0.809 \\
$\mathbf{4}$ & Customer-Oriented Strategy & COS & 0.864 \\
$\mathbf{5}$ & Low-Cost Strategy & LCS & 0.906 \\
$\mathbf{6}$ & Opportunistic Behaviors & OPB & 0.860 \\
$\mathbf{7}$ & Business Performance Efficiency & BP & 0.941 \\
\hline
\end{tabular}

\section{2. $E F A$}

After testing the appropriateness of the scale, the study analyzed the discovery factor EFA for both the variables, the intermediate variable, and the dependent variable. For the independent and intermediate variables, the EFA analysis was conducted twice, in which the factor loading in each analysis was $>0.5$, showing the appropriate correlation between the variables observed (indicators) and selected factors in the model. However, in the first analysis, because "convergence value" does not guarantee the same factor, the LC3 indicator was rejected. The second analysis shows that the remaining data are eligible for analysis due to factor load coefficients $>0.5$ and satisfy two conditions, "Convergence value" (observed variables converge to the same one factor) and "Distinguishing value" (observed variables belonging to one factor distinguish from another) (see Table 2). With the dependent variable being business performance, the analytical results showed that the KMO coefficient was $0.905(>0.5)$, the Sig of Bartlett's test was $0.000(<0.05)$, the total variance extracted was $79.480 \%(>50 \%)$. At the same time, the indicators of the scale are combined into a single group, ensuring the "convergence value" of the scale.

Table 2

Results of factor analysis EFA for the independent and intermediate variables

\begin{tabular}{cccccc}
\hline EFA analysis & $\begin{array}{c}\text { KMO } \\
\text { coefficient }\end{array}$ & P-value & $\begin{array}{c}\text { Average } \\
\text { Variance } \\
\text { Extracted }\end{array}$ & Factors loading & Conclusion \\
\hline The 1nd time & 0.925 & 0.000 & 61.718 & All are $>0.5$ & All are $>0.5$ \\
The 2nd time & 0.924 & 0.000 & 62.623 & $\begin{array}{c}\text { Guaranteed analysis } \\
\text { requirements }\end{array}$ \\
\hline
\end{tabular}


Analysis results show the appropriateness of the measurement model. Chi-square $=1631,061, \mathrm{df}=644, \mathrm{Chi}$-square $/ \mathrm{df}=$ $2,533(<5), \mathrm{P}=0.000, \mathrm{GFI}=0.872(>0.8), \mathrm{TLI}=0.924(>0.8), \mathrm{CFI}=0.931(>0.8), \mathrm{RMSEA}=0.051(<0.08)$.

\subsection{SEM Analysis}

Conducting analysis of the SEM model for the research model, we see that the synthetic indicators are satisfactory. Specifically, Chi-square $=2509.916, \mathrm{df}=653$, Chi-square $/ \mathrm{df}=3.844(<5), \mathrm{P}=0.000, \mathrm{GFI}=0.801(>0.8), \mathrm{TLI}=0.860(>0.8), \mathrm{CFI}=0.870$ $(>0.8)$, RMSEA $=0.069(<0.08)$ (see Fig. 2).

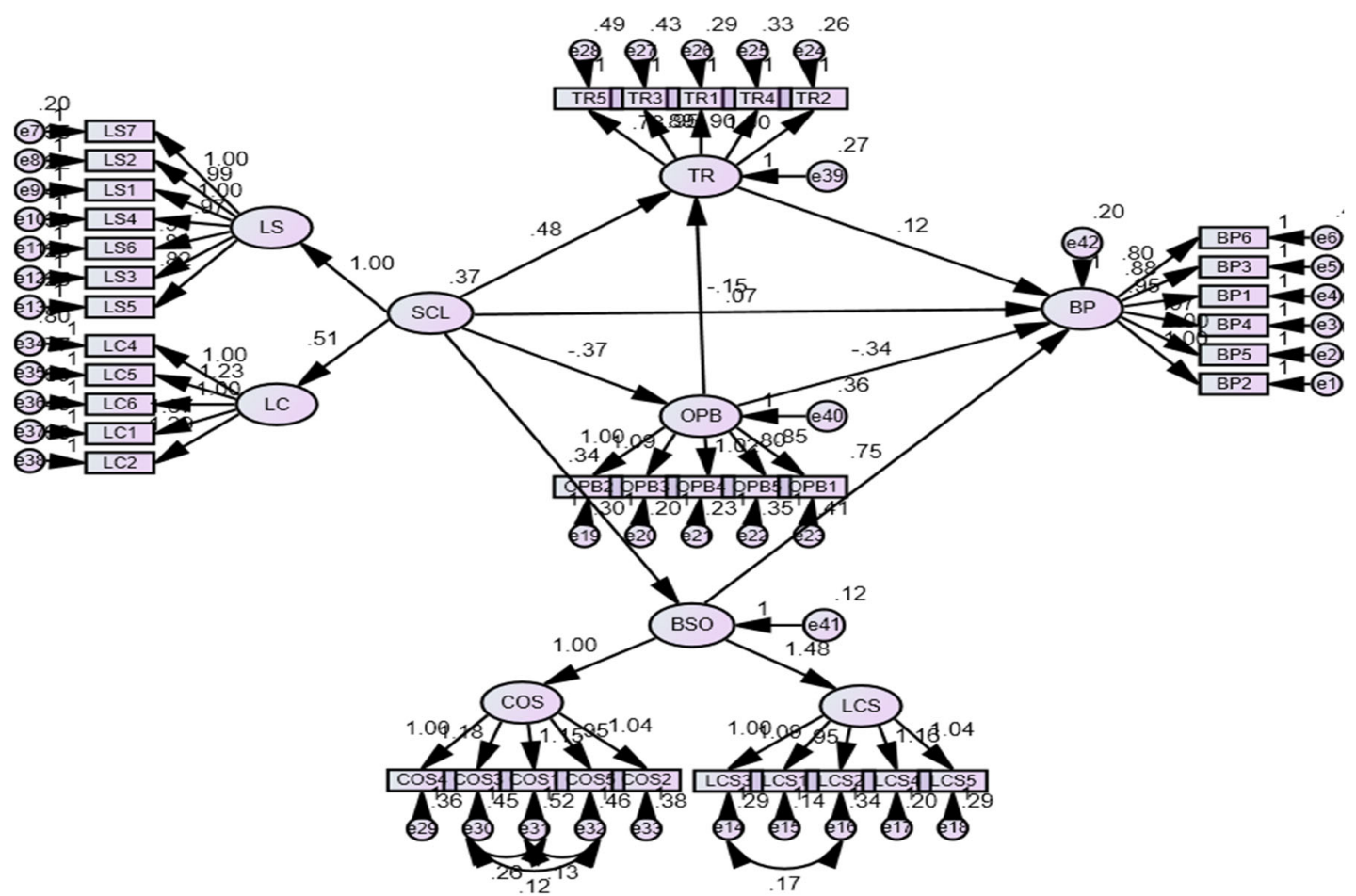

Fig. 2. Analysis of the SEM model

The results of estimating the relationships in the model show that the research model is appropriate. Except for hypothesis $\mathrm{H} 1$, all the remaining hypotheses with significance level $\mathrm{p}<0.05$ are accepted. Specifically, hypothesis $\mathrm{H} 1$ is rejected because the significance level $\mathrm{p}$ is $0.162>0.05$. That is, there is no impact of supply chain linkages on enterprises' business performance. This result is contrary to the work of Li et al. (2006); Paulraj (2007); Harrigan (1984); David (1993); Lee and Whang (2000); Jones and Riley (1985); Stevens (1989); Cooper et al. (1997); Tyndall et al. (1998); Worms and Brand (1996); Droge et al. (2004); Flynn et al. (2010) ... but agree with the study of Rosenzweig et al. (2003); Vickery et al. (2003), etc. At the same time, research has shown that supply chain linkages indirectly affect business performance through other intermediaries. This is the problem that enterprises need to pay attention to have the most effective strategies and solutions. Hypotheses $\mathrm{H} 2$ and $\mathrm{H} 3$ are accepted with both significance $<0.05$ and positive regression weights. It shows that the link positively affects trust among members in the supply chain. It means the conclusion that supply chain linkages positively affect the direction of business strategy, thereby positively affecting the business performance of enterprises. These results correspond to the studies of George and Jones (1996); David (1993); Lee and Whang (2000); Bakiev (2013); Guinot et al. (2014); Klein and Rai (2009), etc. Similarly, with significance $\mathrm{P}<0.05$ and positive regression weights, the hypotheses H4 and $\mathrm{H} 5$ are also accepted. Synonymous with the conclusion, supply chain linkages positively impact the direction of business strategy, thereby positively impacting the business performance of enterprises. This result also corresponds to the research of Grant (1991); Han et al. (1998); Habib and Victor (1991), etc. Hypothesis H6 and H7 test the impact of linkage on opportunistic behavior of members in the supply chain and the impact of opportunistic behaviors on the business performance of enterprises in Vietnam. The research results show that, with the significance levels $<0.05$ and negative regression weights, the hypothesis $\mathrm{H} 6$ and $\mathrm{H} 7$ are accepted. Therefore, it can be concluded that the link has a negative impact on the opportunistic behaviors of all members in the supply chain and thereby on business performance. These conclusions are like the studies of Zsidisin (2003); Trkman and McCormack (2009); Katsikeas et al. (2009), etc. Thus, with the rejection of hypothesis H1, while accepting all the remaining hypotheses, it can be concluded that supply chain linkages, although not having a direct impact, has an indirect impact on operational efficiency. Enterprise's business through intermediaries is the trust, strategic business orientation, and the opportunistic behaviors of the participating members (see Table 3 ). 
Also, the hypothesis H8 with a significance level $\mathrm{P}<0.05$ and a regression weight of -0.146 is also accepted. This also proves that opportunistic behaviors negatively impact trust among members in the supply chain. This result corresponds to the works of Morgan and Hunt (1994); Giunipero and Brand (1996); Droge et al. (2004), etc.

Table 3

SEM analysis results for the relationships in the model

\begin{tabular}{ccccccc}
\hline Hypothesis & Relationship & Weightage & S.E & C.R. & P & Conclusion \\
\hline H1 & BP $\leftarrow$ SCL & 0.068 & 0.049 & 1.398 & 0.162 & Rejected \\
H2 & TR $\leftarrow$ SCL & 0.475 & 0.050 & 9.475 & 0.000 & Accept \\
H3 & BP $\leftarrow$ TR & 0.123 & 0.044 & 2.798 & 0.005 & Accept \\
H4 & BSO $\leftarrow$ SCL & 0.341 & 0.035 & 9.657 & 0.000 & Accept \\
H5 & BP $\leftarrow$ BSO & 0.748 & 0.077 & 9.708 & 0.000 & Accept \\
H6 & OPB $\leftarrow$ SCL & -0.366 & 0.049 & -7.487 & 0.000 & Accept \\
H7 & BP $\leftarrow$ OPB & -0.336 & 0.038 & -8.869 & 0.000 & Accept \\
H8 & TR $\leftarrow$ OPB & -0.146 & 0.044 & -3.279 & 0.001 & Accept \\
\hline
\end{tabular}

Thus, we can see the importance of supply chain linkages and the intermediate role of trust, business strategy orientation, and opportunity behavior for the business performance of the enterprises. To have a better practical relationship, the research will determine the average value of each element in this study for enterprises in Vietnam. With the highest average value among the variables included in the model is 3,8100, enterprises' customer-oriented strategy is assessed at a rather high level. This shows enterprises' steps in the right direction in the process of approaching and building long-term relationships with customers. However, if compared with the general index of other factors in management and business activities, this index is still at a relatively averaged level. Meanwhile, the mean value of the opportunistic behaviors is 2.1625 , compared to other factors in the model, which is the lowest-rated factor, reflecting a positive side in management activities. However, this is still a relatively high number compared to a factor that reflects the negative side of the business. Enterprises, when participating in association relationships, need to pay more attention to the opportunistic behaviors of other members. It is necessary to have measures to prevent and build tight ties in economic relations. Strengthen control activities to limit rewarding behaviors and self-reliance in business (see Table 4).

Table 4

The results of statistical analysis describing the values of the variables

\begin{tabular}{cccccc}
\hline Variables & N & Min & Max & Mean & Std. Deviation \\
\hline SCL & 598 & 1.79 & 5.00 & 3.5986 & 0.53588 \\
LS & 598 & 1.00 & 5.00 & 3.7551 & 0.61048 \\
LC & 598 & 1.80 & 5.00 & 3.4421 & 0.62540 \\
TR & 598 & 1.20 & 5.00 & 3.7385 & 0.61817 \\
BSO & 598 & 1.20 & 4.90 & 3.7211 & 0.58251 \\
COS & 598 & 1.00 & 5.00 & 3.8100 & 0.63597 \\
LCS & 598 & 1.00 & 5.00 & 3.6321 & 0.69072 \\
OPB & 598 & 1.00 & 5.00 & 2.1625 & 0.65938 \\
BP & 598 & 1.00 & 5.00 & 3.7963 & 0.65772 \\
\hline
\end{tabular}

\section{Conclusions and Recommendations}

The research aims to test the impact of supply chain linkages on the business performance of enterprises. With the context of enterprises in Vietnam, the research results show that supply chain linkages, though not having a direct impact, have an indirect impact on the business performance of enterprises through intermediaries is the belief, strategic business orientation, and the opportunistic behaviors of the participating members. Also, the research shows that opportunistic behaviors have negative effects on trust among members in the supply chain. In addition to those contributions, research also has certain limitations. Convenient sampling is a limitation of the study, which can reduce the ability to control the representativeness of the sample. At the same time, the research context is limited to businesses in Vietnam. With the results achieved, the paper opens a development orientation in which research will be deployed in other countries in the region and in the world. Based on the research results, the group of authors proposes several recommendations to improve the business performance of enterprises through solutions to create sustainable linkages in the supply chain and related other factors.

Firstly, concerning supply chain linkages, it is necessary to agree on appropriate mechanisms in building links to ensure the harmonization of interests between stakeholders. It should not be too important that the low cost affects the service, the product (lack of quality goods, violation of regulations on food safety and hygiene), or too important to the customer to make the strict request with major suppliers. Besides, enterprises need to stabilize and gradually expand the market, and at the same time, diversify export products. 
Second, with trust among members in the supply chain, it is necessary to create a friendly and fair collaborative environment, which encourages open and straightforward information sharing among supply chain members. Create good relationships between enterprises and customers, showing their confidence in the joint working ability of partners and suppliers.

Third, with the business strategy, there should be strategies to support the connection and development in different directions between enterprises and suppliers, and customers, ensuring stable output and raw materials and high-quality input. There should be a combination of cost-fairness across the supply chain and customer satisfaction.

Fourth, with the opportunistic behaviors of members participating in the supply chain, there should be measures to prevent, build tight ties in economic relations and targets in cooperation activities. Encourage information sharing among members participating in the supply chain. Strengthen control activities to limit rewarding behaviors and self-reliance in business.

\section{References}

Anderson, J.C., \& Narus, J.A. (1990). A model of distributor firm and manufacturer firm working partnerships. Journal of Marketing, $54,42-58$.

Bakiev, E. (2013). The Influence of Interpersonal Trust and Organizational Commitment on Perceived Organizational Performance. Journal of Applied Economics and Business Research, 3(3), 166-180.

Beamon, B.M. (1999). Measuring supply chain performance. International Journal of Operations \& Production Management, 19(3), 275292.

Bechtel, C., \& Jayaram, J. (1997). Supply chain management: A strategic perspective. The international Journal of Logistics Management, $8(1), 15-34$

Cohen, M.A., \& Isaac, M.S. (2021). Trust Does Beget Trustworthiness and Also Begets Trust in Others. Social Psychology Quarterly, 84(2), 189-201.

Cooper, M.C., Lambert, D.M., \& Pagh, J.D. (1997). Supply chain management: more than a newname for logistics. International Journal of Logistics Management, 8(1), 1-14.

Chen, I.J., \& Paulraj, A. (2004). Towards a theory of supply chain management: the constructs and meansurement. Journal of Operations Managements, 22, 119-150.

Christopher, M. (1998). Logistics and Supply Chain Management: Strategies for Reducing Cost and Improving Service. Financial Times: Pitman Publishing, London.

David, T. (1993). Effective supply chain management. Sloan Management Review, 34(4), 35-46.

Delaney, J.T., \& Huselid, M.A. (1996). The impact of human resource management practices on perceptions of organizational performance. Academy of Management Journal, 39(4), 949-969.

Deshpande, R., \& Farley, J.U. (1998). Measuring marketing orientation: generalization and synthesis. Journal of Marketing - Focused Management, 2, 213-232.

Deshpande, R., John, U.F., \& Frederick, E.W. (1993). Corporate Culture, Customer Orientation, and Innovativeness in Japanese Firms: A Quadrad Analysis. Journal of Marketing, 57(1), 23-37.

Dollinger, M.J., \& Golden, P.A. (1992). Interorganizational and Collective Strategies in Small Firms: Environmental Effects and Performance. Journal of Management, 18(4), 695-715.

Droge, C., Jayaram, J., \& Vickery, S. (2004). The effects of internal versus external integration practices on time-based performance and overall firm performance. Journal of Operations Management, 22 (6), 557-573.

Enkel, E., Kausch, C., \& Gassmann, O. (2005). Managing the risk of customer integration. European Management Journal, 23(2), 203213.

Fabbe-Costes, N., \& Jahre, M. (2008). Supply chain integration and performance: a review of the evidence. The International Journal of Logistics Management, 19(2), 130-154.

Flynn, B.B., Huo, B., \& Zhao, X. (2010). The impact of supply chain integration on performance: a contingency and configuration approach. Journal of Operations Management, 28(1), 58-71.

Frohlich, M.T., \& Westbrook, R. (2001). Arcs of integration: An international study of supply chain strategies. Journal of Operations Management, $19(2), 185-200$.

Gatignon, H., \& Xuereb, J.M. (1997). Strategic orientation of the firm and new product performance. Journal of Marketing Research, 34(1), 77-90.

George, J.M., \& Jones, G.R. (1996). The experience of work and turnover intentions: Interactive effects of value attainment, job satisfaction, and positive mood. Journal of Applied Psychology, 81(3), 318-325.

Grant, R.M. (1991). The Resource-Based Theory of Competitive Advantage: Implications for Strategy Formulation. California Management Review, 33(3), 114-135.

Guinot, J., Chiva, R., \& Mallen, F. (2014). Organizational trust and performance: Is organizational learning capability a missing link?. Journal of Management \& Organization, 19, 559-582.

Giunipero, L.C., \& Brand, R.R. (1996). Purchasing's Role in Supply Chain Management. The International Journal of Logistics Management, 7(1), 29-38.

Habib, M.M., \& Victor, B. (1991). Strategy, structure, and performance of U.S. manufacturing and service MNCs: A comparative analysis. Strategic Management Journal, 12(8), 589-606.

Hair, J.F., Anderson, R.E., Tatham, R.L., \& Black, W.C. (1998). Multivariate Data Analysis (5th Edition). Upper Saddle River, NJ: PrenticeHall.

Han, J.K., Kim, N., \& Srivastava, R.K. (1998). Market Orientation and Organizational Performance: Is Innovation a Missing Link?. Journal of Marketing, 62(4), 30-45.

Handfield, R.B., \& Nichols, E.L. (1999). Introduction to Supply Chain Management, Prentice-Hall, Upper Saddle River, NJ.

Harrigan, K.R. (1984). Formulating vertical integration strategies. Academy of Management Review, 9(4), 638-652.

Higgins, J.M., \& Vincze, J.W. (1989). Strategic Management Text and Cases, New York, NY: The Dryan Press.

Huselid, M.A. (1995). The Impact Of Human Resource Management Practices On Turnover, Productivity, And Corporate Financial Performance. Academy of Management Journal, 38(3), 635-672.

Jones, T., \& Riley, D.W. (1985). Using inventory for competitive advantage through supply chian management. International Journal of Physical Distribution and Materials Management, 15(5), 16-26. 
Kankaew, K., Yapanto, L.M., Waramontri, R., Arief, S., Hamsir, H., Sastrawati, N., Maguina, M.R.E. (2021). Supply chain management and logistic presentation: Mediation effect of competitive advantage. Uncertain Supply Chain Management, 9(2), 255-264.

Kaplan, R.S., \& Norton, D.P. (1993). Implementing the balanced scorecard at FMC corporation: An interview with Larry D. Brady. Harvard Business Review, 71(5), 143-147.

Katsikeas, C.S., Dionysis, S., \& Daniel, C. (2009). Developing successful trust-based international exchange relationships. Journal of International Business Studies, 40(1), 132-155.

Kettinger, W.J., Lee, C.C., \& Lee, S. (1995). Global Measures of Information Services Quality: A Cross-National Study. Decision Sciences, 26(5), 569-588.

Klein, R., \& Rai, A. (2009). Interfirm strategic information flows in logistics supply chain relationships. MIS Quarterly, 33(4), 735-765.

La Londe, B.J. (1998). Supply chain evolution by the numbers. Supply Chain Management Review, 2(1), 7 - 8.

Lee, H.L., \& Whang, S. (2000). Information sharing in a supply chain. International Journal of Technogogy Management, 20(3), $373-387$.

Li, S., Ragu-Nathan, B., Ragu-Nathan, T.S, \& Rao, S.S. (2006). The impact of supply chain management practieson competitive advantage and organizational performance. The International Journal of Management Science, 34, 107-124.

Lummus, R.R., \& Vokurka, R.J. (1999). Defining supply chain management: a historical perspective and practical guidelines. Industrial Management and Data Systems, 99(1), 11-17.

Maisel, L.S. (2001). Performance measurement practices survey results. Ewing, NJ: American Institute of Certified Public Accountants.

Martin, J., \& Grbac, B. (2003). Using Supply Chain Management to Leverage a Firm's Market Orientation. Industrial Marketing Management, 32(1), 25-38.

Maryer, R.C., Davis, J.H., \& Schoorman, F.D. (1995). An Integrative Model of Organizational Trust. The Academy of Management Review, 30(3), 709-734.

Mentzer, J.T., DeWitt, W., Keebler, J.S., Min, S., Nix, N.W., \& Zacharia, Z.G. (2001). Defining supply chain management. Journal of Business Logistics, 22(2), 1-25.

Morgan, R.M., \& Hunt, S.D. (1994). The commitment-trust theory of relationship marketing. Journal of Marketing, 58(3), 20-38.

Narver, J.C., \& Slater, S.F. (1990). The effect of Market Orientation on Business Profitability. Journal of Marketing, 59(3), 63-74.

Neely, A., Gregory, M., \& Platts, K. (1995). Performance measurement system design: a literature review and research agenda. International Journal of Operations \& Production Management, 15(4), 80-116.

Nielsen, C. (2019). From innovation performance to business performance: Conceptualising a framework and research agenda. Meditari Accountancy Research, 27(1), 2-16.

Nguyen, H.N., Le, Q.H., Tran, Q.B., Tran, T.H.M., Nguyen, T.H.Y., \& Nguyen, T.T.Q. (2020). The Impact of Organizational Commitment on Employee Motivation: A Study in Vietnamese Enterprises. Journal of Asian Finance, Economics, and Business, 7(6), $439-447$.

Nguyen, T.M.P., Tran, Q.B., Do, D.T. \& Tran, D.L. (2020). Impact of corporate social responsibility toward employees on business performance: The case of Vietnam, Uncertain Supply Chain Management, 8(3), 589-598.

Paulraj, A. (2007). Environmental Uncertainty and Strategic Supply Management: A Resource Dependence Perspective and Performance Implications. The Journal of Supply Chain Management, 43(3), 29-42.

Porter, M.E. (1985). The Competitive Advantage: Creating and Sustaining Superior Performance, Faculty \& Research, Harvard Business School.

Rosenzweig, E., Roth, A., \& Dear, Jr.J. (2003). The influence of an integration strategy on competitive capacities and business performance: An exploratory study of consumer products manufacturers. Journal of Operations Management, 21,437-456.

Stevens, G.C. (1989). Integrating the supply chain. International Journal of Physical Distribution \& Materials Management, $19(8), 3-8$.

Swink, M., Narasimhan, R., \& Wang, C. (2007). Managing beyond the factory walls: Effects of four types of strategic integration of many facturing plant performance. Journal of Operations Management, 25, 148-164.

Taylor, S., Sharland, A., Cronin, J., \& Bullard, W. (1993). Recreational Service Quality in the International Setting. International Journal of Service Industry Management, 4, 68-86.

Tyndall, G., Christopher, G., Partsch, W., \& Kamauff, J. (1998). Supercharging supply chain: New ways to increase value through global operation excellence, New York, NY: John Wiley \& Sons.

Tran, Q.B., Le, Q.H., Nguyen, H.N., Tran, D.L., Nguyen, T.T.Q., \& Tran, T.T.T. (2021). The Impact of Brand Equity on Employee's Opportunistic Behavior: A Case Study on Enterprises in Vietnam. Journal of Risk and Financial Management, 14(4), 164.

Trkman, P., \& McCormack, K. (2009). Supply Chain Risk in Turbulent Environments-A Conceptual Model for Managing Supply Chain Network Risk. International Journal of Production Economics, 119(2), 247-258.

Venkatraman, N., \& Ramanujam, V. (1986). Measurement of Business Performance in Strategy Research: A Comparison of Approaches. Academy of Management Review, 11(4), 801-814.

Vickery, S., Jayaram, J., Droge, C., \& Calatone, C. (2003). The effects of an integrative supply chian strategy on service and finacial performace: an analysis of direct versus indirect relationships. Journal of Operations Management, 21, 523-539.

Williamson, O.E. (1975). Markets and Hierarchies: Analysis and Antitrust Implications, New York: Free Press.

Zelbst, P.J., Green, K.W., Sower, V.E., \& Reyes, P. (2009). Impact of supply chain linkages on supply chain performance. Industrial Management \& Data Systems, 109(5), 665-682.

Zhao, L., Sun, L., \& Zhao, X. (2013). The impact of supply chain risk on supply chain integration and company performance: a global investigation. Supply chain management: An International Journal, 182, 115-131.

Zsidisin, G.A. (2003). A grounded definition of supply risk. Journal of Purchasing and Supply Management, 9(5), $217-224$.

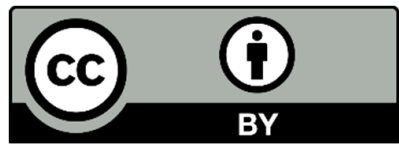

(C) 2021 by the authors; licensee Growing Science, Canada. This is an open access article distributed under the terms and conditions of the Creative Commons Attribution (CCBY) license (http://creativecommons.org/licenses/by/4.0/). 